\title{
ASPEK SANITASI DAN HIGIENE DI KANTIN ASRAMA TINGKAT PERSIAPAN BERSAMA (TPB) INSTITUT PERTANIAN BOGOR ${ }^{1)}$
}

\author{
(Sanitation and Hygiene Aspects at TPB Dormitory's Canteen, \\ Bogor Agricultural University)
}

Evy Damayanthi ${ }^{2}$, Lilik N. Yuliati ${ }^{3}$, Vitriani Y. Suprapti ${ }^{4}$ dan Fitriana Sari ${ }^{4}$

1 Sebagian hasil Hibah Penelitian yang didanai oleh Proyek Due-like TA 2004
2 Staf Pengajar Departemen Gizi Masyarakat, Fakultas Ekologi Manusia (FEMA), IPB
Telp: 0251-8628304/8621258; Fax: 0251-8625846/8622276
${ }^{3}$ Staf Pengajar Departemen Ilmu Keluarga dan Konsumen, Fakultas Ekologi Manusia (FEMA), IPB
Telp: 0251-8628303/8627432; Fax: 0251-8625846/8622276
${ }^{4}$ Alumnus Program Studi Gizi Masyarakat dan Sumberdaya Keluarga, Fakultas Pertanian (FAPERTA) IPB.

\begin{abstract}
ABST RACT
The major purpose of this research was to analyze sanitation and hygiene at TPB IPB Dormitory's Canteens. Microbiological analysis (sanitation analysis) was done on chef's hands and some utensils (eating plate, serving plate, and chopping board). There were a lot of Staphylococcus found in food handler's hands (19-57 CFU). This research showed that there was no tendency which was the worst canteen from the three canteens at boy's dormitory or girl's dormitory. The statistical analysis showed that the location of the canteen and kind of utensils influenced the total Enterobacter. The chef's hands of $\mathrm{Cl}$ and A3 canteens contained E. coli bacteria, but the other chef's hands, did not. Eating plate, serving plate, and chopping board from Canteens $\mathrm{A} 3$ and $\mathrm{C} 1$ were not safe due to the number of microbes they had $\left(1.08 \times 10^{2}-3.6 \times 10^{2} \mathrm{CFU} / \mathrm{cm}^{2}\right)$. All utensils at canteen $\mathrm{Al}$ were safe. C2's and C3's chopping boards were not safe, but their eating plate and serving plate were safe.
\end{abstract}

Keywords: sanitation, hygiene, Dormitory's Canteen, microbiology test, utensil

\section{PENDAHULUAN}

\section{Latar Belakang}

Keamanan pangan menempati posisi yang penting bagi kesehatan dan pembangunan. UU No 7 tahun 1996 yang memuat tentang Keamanan Pangan pada Bab II telah diperkuat dengan keluarnya PP No. 28 tahun 2004 tentang Keamanan, Mutu dan Gizi Pangan. Dengan demikian setiap produk makanan yang beredar di masyarakat harus terjamin mutu dan keamanannya agar tidak merugikan konsumen.

Salah satu faktor penting yang mendukung keamanan pangan adalah sanitasi. Sanitasi mencakup cara kerja yang bersih dan aseptik dalam berbagai bidang, meliputi persiapan, pengolahan, penyiapan maupun transpor makanan, kebersihan dan sanitasi ruangan dan alat-alat pengolahan pangan, serta kebersihan dan kesehatan pekerja di bidang pengolahan dan penyajian (Marriot, 1999; Jenie \& Fardiaz, 1989).
Badan POM melaporkan Kejadian Luar Biasa (KLB) keracunan pangan tahun 2004 berjumlah 152. Karakteristik epidemiologinya menunjukkan makanan rumahtangga merupakan penyebab keracunan pangan tertinggi (46.7\%), kemudian jasa boga (22.4\%). Sekolah atau kampus merupakan tempat terjadinya KLB keracunan pangan kedua terbanyak $(2.7 \%)$ setelah tempat tinggal (39.5\%) (BPOM, 2005).

Sejak tahun 2002, IPB mewajibkan mahasiswa Tingkat Persiapan Bersama (TPB) tinggal di asrama. Setiap gedung asrama dilengkapi dengan sebuah kantin, di mana asrama putri memiliki 3 buah kantin (A1, A2, dan A3) dan asrama putra memiliki 3 buah kantin (C1, C2, dan (3). Kantin asrama merupakan jasa boga golongan $\mathrm{B}$ menurut penggolongan PP Menkes RI No. 712/MEN.KES/PER/X/1986 tentang Persyaratan Kesehatan Jasa Boga. Mengingat sebagian besar mahasiswa TPB makan di kantin Asrama, maka keamanan pangan penting bagi kehidupan serta keberhasilan studi mahasiswa TPB-IPB. 
Dalam mempersiapkan makanan hingga menyajikannya, pihak pengelola kantin harus benar-benar memperhatikan masalah keamanan pangan. Melihat kondisi kebersihan kantin dan penerapan prinsip higiene food handler yang masih kurang, menimbulkan pertanyaan seberapa bersih tangan food handler dan peralatan makan secara mikrobiologis. Melalui informasi tersebut, diharapkan dapat dilakukan upaya-upaya pengembangan keamanan pangan di kantin asrama TPB-IPB.

\section{$\underline{\text { Tujuan }}$}

Secara umum tujuan dari penelitian ini adalah untuk mempelajari aspek sanitasi dan higiene di kantin asrama TPB-IPB dan secara khusus untuk menganalisis pengaruh lokasi kantin dan kebersihan tangan juru masak terhadap total mikroba, Escherichia coli, Enterobacter aerogenes, dan Staphylococcus; serta menganalisis pengaruh lokasi kantin dan jenis alat terhadap jumlah kapang dan khamir, bakteri proteolitik dan spora bakteri peralatan.

\section{METODE}

\section{Desain, Tempat, dan Waktu Penelitian}

Desain penelitian ini adalah cross sectional study. Pengambilan data dilakukan di Kantin Asrama Tingkat Persiapan Bersama (TPB) - IPB sedangkan analisis laboratorium dilakukan di Laboratorium Mikrobiologi Departemen Gizi Masyarakat dan Sumberdaya Keluarga, Fakultas Pertanian, IPB. Kegiatan penelitian dilakukan mulai bulan April sampai November 2004.

\section{Bahan dan Alat}

Obyek yang diuji adalah tangan juru masak, piring makan, piring saji, dan talenan. Bahan yang digunakan yaitu media mikrobiologis Plate Count Agar, Eosin Methylene Blue Agar, Staphylococcus Medium 110, Potato Dextrose Agar, Nutrient Agar, Skim Milk Agar yang terbuat dari Plate Count Agar dan 2\% susu skim. Alat yang digunakan antara lain otoklaf, inkubator, dan Darkfield Colony Counter.

\section{Jenis dan Cara Pengumpulan Data}

Contoh diambil dari semua Kantin Asrama Putri-Putra TPB-IPB. Contoh diambil secara purposive: 1) Uji kebersihan tangan Food Handler: juru masak; 2) Uji sanitasi peralatan meliputi talenan, piring saji, dan piring makan yang kondisinya masih bersih/belum dipakai. Data uji sanitasi tangan juru masak dikategorikan menjadi 4: sedikit (1-3 CFU/ cawan), agak banyak (4-6 CFU/cawan), banyak (7-10 CFU/cawan) dan banyak sekali (>11 CFU/cawan) (Kuswanti, 2002).

Untuk uji sanitasi peralatan pengambilan contoh talenan dan piring saji, dilakukan pukul 06.00-07.00 WIB, sedangkan piring makan dan tangan juru masak, pukul 10.0012.00 WIB. Contoh dimasukkan ke termos es yang telah disterilkan dengan alkohol lalu diisi es batu dan dibawa ke laboratorium (lama perjalanan 15-30 menit) untuk langsung dianalisis. Contoh tangan juru masak diamati kandungan total mikroba, E. coli, E. aerogenes, dan Staphylococcus; sedangkan peralatan diamati jumlah kapang dan khamir, bakteri proteolitik dan spora bakteri (Fardiaz, 1992). Jumlah koloni pada setiap cawan dihitung dan dinyatakan dalam jumlah koloni per $\mathrm{cm}^{2}$ permukaan alat dengan perhitungan sebagai berikut (Fardiaz, 1992):

Jumlah koloni per $\mathrm{cm}^{2}$ permukaan alat $=$ fjumlah koloni dalam $1.0 \mathrm{ml}$ atau jumlah koloni dalam $0.1 \mathrm{ml} \times 10 \times 1 / 50\}$

Data uji sanitasi tangan juru masak setiap kantin pada Asrama putri dan putra dianalisis menggunakan pendekatan Acak Lengkap dengan dua kali ulangan. Faktor dalam rancangan adalah tangan food handler yang terdiri dari tiga taraf yaitu tangan food handler kantin A1, A2, dan A3 untuk Asrama putri serta kantin C1, C2, dan C3 untuk Asrama putra. Model matematis rancangan :

$$
\begin{gathered}
Y_{i j}=\mu+\tau_{i}+\varepsilon_{i j} \\
i=1,2,3 ; j=1,2
\end{gathered}
$$

$Y_{i j}=$ Jumlah mikroba pada tangan juru masak kantin ke-i, ulangan ke-j

$\mu=$ Rataan umum

$\tau_{\mathrm{i}}=$ Pengaruh tangan juru masak kantin ke-i

$\varepsilon_{\mathrm{ij}}=$ Pengaruh acak pada tangan juru masak kantin ke-i dengan ulangan ke-j

Uji sanitasi alat pengolahan di setiap kantin Asrama putri-putra dianalisis dengan pendekatan Faktorial Tersarang dengan dua kali ulangan. Faktornya adalah kantin dengan tiga taraf yaitu kantin C1, C2, dan C3 untuk Asrama putri serta kantin A1, A2, dan A3 untuk Asrama putra. Alat pengolahan berperan sebagai faktor yang tersarang di dalam faktor kantin dan terdiri dari tiga taraf yaitu piring makan, piring saji, dan talenan. Bentuk umum dari model linier rancangan ini :

$$
\begin{gathered}
Y_{i j k}=\mu+\tau_{i}+B_{j(i)}+\varepsilon_{k(i j)} \\
i=1,2,3 ; j=1,2,3 ; k=1,2
\end{gathered}
$$




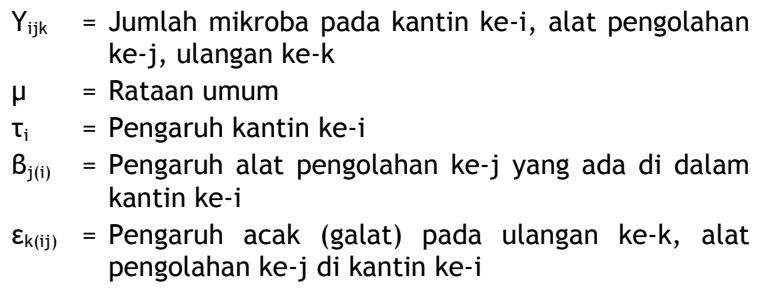

\section{HASIL DAN PEMBAHASAN}

\section{Kantin Asrama Putri TPB-IPB}

\section{Higiene tangan juru masak}

Jumlah total mikroba berkisar 1-88 koloni dan total mikroba pada tangan juru masak A1 memiliki jumlah tertinggi (Tabel 1). Lokasi kantin tidak berpengaruh terhadap jumlah total mikroba $(p>0.05)$. E. Coli hanya ditemukan pada tangan juru masak A3, sebaliknya A1 dan A2 tidak ada, sedangkan jumlahnya tidak dipengaruhi oleh lokasi kantin ( $p>0.05)$.

Hasil total mikroba memperlihatkan tidak ada tangan juru masak yang bebas mikroba. Karena pengambilan contoh dilaku dilakukan setelah juru masak mencuci tangan dengan air, berarti pencucian tangan dengan air saja tidak dapat menghilangkan mikroba. Kantin tidak memiliki fasilitas cuci tangan dan kamar mandi.

Tabel 1. Jumlah Mikroba Indikator Sanitasi pada Tangan Juru Masak di Kantin Asrama Putri TPB-IPB

\begin{tabular}{|c|c|c|c|c|}
\hline \multirow[b]{2}{*}{ Kantin } & \multicolumn{4}{|c|}{ Jenis mikroba indikator sanitasi } \\
\hline & $\begin{array}{c}\text { Total } \\
\text { Mikroba }\end{array}$ & E. coli & $\begin{array}{l}\text { E. aero- } \\
\text { genes }\end{array}$ & $\begin{array}{c}\text { Staphylo- } \\
\text { coccus }\end{array}$ \\
\hline $\mathrm{A} 1$ & $\begin{array}{c}\text { Banyak } \\
\text { sekali }\end{array}$ & $\begin{array}{c}\text { Tidak } \\
\text { ada }\end{array}$ & Sedikit & $\begin{array}{c}\text { Banyak } \\
\text { sekali }\end{array}$ \\
\hline $\mathrm{A} 2$ & Banyak & $\begin{array}{c}\text { Tidak } \\
\text { ada }\end{array}$ & Banyak & $\begin{array}{c}\text { Banyak } \\
\text { sekali }\end{array}$ \\
\hline $\mathrm{A} 3$ & Sedikit & Sedikit & Tidak ada & $\begin{array}{c}\text { Banyak } \\
\text { sekali }\end{array}$ \\
\hline
\end{tabular}

Keterangan: - tidak ada (0 CFU/cawan)

- banyak (7-10 CFU/cawan)

- sedikit (1-3 CFU/cawan)

- banyak sekali (>11 CFU/cawan)

- agak banyak (4-6 CFU/cawan)

Pencucian tangan dengan sabun antiseptik dapat mengurangi total mikroba meskipun pengurangan skornya hanya berkisar antara 0.5-1.0 angka (Kuswanti, 2002). Menurut Jenie (1999), selama pencucian tangan dan terbentuk busa yang kemudian dibilas, akan menghilangkan banyak mikroba patogen yang berasal dari makanan. Pada waktu pencucian tangan, kombinasi aktivitas emulsifikasi dari sabun pada lemak, minyak dan pelumas, efek abrasif dari penggosokan, dan air, akan menghilangkan dan membawa partikel-partikel yang sudah terlepas dan terdispersi yang banyak mengandung mikroorganisme.

Air panas yang biasa digunakan untuk mencuci tangan, tidak cukup panas untuk membunuh bakteri. Lemak tubuh yang terdapat pada kulit tangan akan mengikat kotoran dan bakteri. Air sabun yang bersuhu panas atau hangat lebih efektif daripada air dingin untuk melepaskan lemak tubuh yang mengikat kotoran dan bakteri (Anonim, 2005). Pencucian tangan dengan sabun dan air panas tidak dilakukan, sehingga diduga menyebabkan kandungan Staphylococcus aureus ditemukan "banyak sekali" di tangan food handler.

E. aerogenes tidak ditemukan pada tangan juru masak A3 dengan jumlah yang sedikit di A1 namun banyak di A2 (Tabel 1). Lokasi kantin berpengaruh $(p<0.05)$ terhadap jumlah E. aerogenes. Jumlah E. aerogenes tangan juru masak A2 lebih banyak secara nyata dibandingkan A1 dan A3. Staphylococcus pada tangan food handler dari A1, A2 dan A3 ditemukan banyak sekali, tetapi masih di bawah batas aman (Batas aman: total mik$\mathrm{roba}=100 \mathrm{CFU} / \mathrm{cm}^{2}$, Permenkes RI, 1989).

Penularan terjadi karena mengkonsumsi produk makanan yang mengandung enterotoksin staphylococcus. Makanan yang sering tercemar adalah terutama makanan yang diolah dengan tangan, baik yang tidak segera dimasak dengan baik ataupun karena proses pemanasan atau penyimpanan yang tidak tepat. Bila makanan tersebut dibiarkan pada suhu kamar untuk beberapa jam sebelum dikonsumsi, maka Staphylococcus yang mempro-duksi toksin akan berkembang biak dan akan memproduksi toksin tahan panas (Anonim, 2005).

Enterobacter ikut terdeteksi pada saat menganalisis E. coli. Diduga telah terjadi kontaminasi dari bahan pangan mentah ke tangan food handler pada saat menyiapkan bahan pangan. Enterobacter adalah jenis bakteri pemecah pektin yang banyak ditemukan pada bahan pangan mentah dan di dalam tanah. E. aerogenes merupakan bakteri koliform non fekal yang umumnya ditemukan pada hewan dan tanaman yang telah mati. E. aerogenes tidak bersifat patogen, namun dapat membentuk lendir yang dapat merusak makanan (Fardiaz, 1992).

Manusia merupakan sumber utama kontaminasi makanan. Tangan, rambut, keringat, 
pernafasan manusia merupakan sumber kontaminasi makanan. Food handler dapat membawa bakteri patogen. Penerapan higiene sangat dibutuhkan karena dengan diaplikasikannya prinsip-prinsip sanitasi maka kondisi yang sehat akan diperoleh. Higiene perorangan mengacu pada kebersihan tubuh manusia. Kesehatan food handler yang baik merupakan salah satu upaya dalam mencegah terjadinya penyakit akibat makanan (Marriott, 1999).

\section{Sanitasi peralatan}

Jumlah kapang-khamir talenan tertinggi di A2, sedangkan terendah di A1 (Tabel 2). Kapang-khamir terbanyak terdapat pada talenan (Gambar 1). Jumlah kapang-khamir piring makan di tiga kantin berkisar 2-3 $\mathrm{CFU} / \mathrm{cm}^{2}$. Jumlah tertinggi pada piring saji di A1. Jumlah kapang-khamir pada peralatan sama banyaknya pada $A 1, A 2$, dan $A 3(p>0,05)$, dan $p a-$ da tiga jenis peralatan $(p>0,05)$.
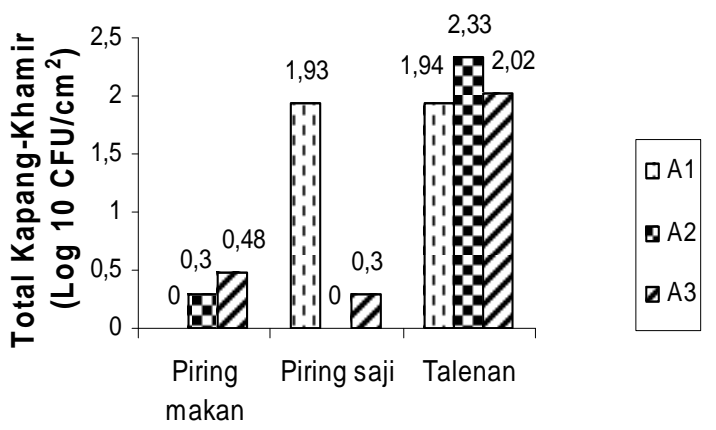

Gambar 1. Jumlah Kapang-Khamir pada Peralatan di Kantin Asrama Putri TPB. IPB

Jumlah bakteri proteolitik berkisar 7-64 koloni $/ \mathrm{cm}^{2}$, di mana pada piring makan dan saji terbanyak di A1. Jumlah bakteri proteolitik talenan di A2 tertinggi, kemudian A3 lalu A1 (Tabel 2; Gambar 2). Tidak terdapat perbedaan nyata $(p>0,05)$ jumlah bakteri proteolitik di A1, A2 dan A3. Untuk spora bakteri piring makan di A1 dan A3 ditemui terendah, sebaliknya pada piring saji di $A 1$ dan $A 3$ tertinggi.

Keberadaan bakteri proteolitik pada piring saji diduga disebabkan pencucian serta penggunaan lap yang kurang bersih. Piring saji tersebut umumnya digunakan untuk meletakkan lauk-pauk yang berprotein tinggi, baik berupa lauk hewani maupun nabati, sehingga bila pencuciannya kurang bersih dapat meninggalkan noda sisa makanan yang bisa menjadi sumber gizi bagi bakteri proteolitik.

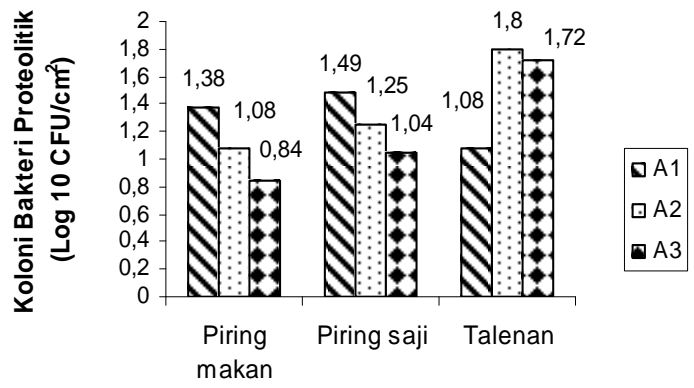

Gambar 2. Koloni Bakteri Proteolitik pada Peralatan di Kantin Asrama Putri TPBIPB

Talenan di A2 menunjukkan jumlah spora bakteri terbanyak. Seperti hasil uji mikroba lainnya, talenan di A2 selalu menunjukkan jumlah tertinggi (Tabel 2 dan Gambar 3). Tidak terdapat perbedaan jumlah spora bakteri $(p>0.05)$, baik antar kantin maupun antar peralatan. Hasil di atas memperlihatkan bahwa berbagai peralatan di dapur ada yang tidak terkontaminasi, namun kebanyakan terkontaminasi. Hal ini perlu diwaspadai karena di dapur bakteri dapat menyebar dari suatu bahan mentah yang akan diolah ke bahan mentah lainnya melalui penggunaaan pisau, spon pencuci piring dan penutup saji. (Anonim, 2003).

Pada asrama putri, berdasarkan jenis alat yang diuji, jumlah kapang dan khamir, bakteri proteolitik dan spora bakteri paling ba-

Tabel 2. Jumlah Mikroba $\left(\mathrm{CFU} / \mathrm{cm}^{2}\right)$ berdasar kan kategori peralatan

\begin{tabular}{|c|c|c|c|c|c|c|}
\hline Kantin & Peralatan & $\begin{array}{c}\text { Kapang \& } \\
\text { Khamir }\end{array}$ & $\begin{array}{c}\text { Bakteri } \\
\text { Proteolitik }\end{array}$ & $\begin{array}{c}\text { Spora } \\
\text { Bakteri }\end{array}$ & Total & Kategori* \\
\hline \multirow{3}{*}{ A1 } & Piring Makan & 0 & $2.4 \times 10^{1}$ & $1 \times 10^{0}$ & $2.5 \times 10^{1}$ & Aman \\
\hline & Piring Saji & $8.6 \times 10^{1}$ & $3.1 \times 10^{1}$ & $2 \times 10^{0}$ & $1.19 \times 10^{2}$ & Tidak Aman \\
\hline & Talenan & $8.8 \times 10^{1}$ & $1.2 \times 10^{1}$ & $1 \times 10^{0}$ & $1.08 \times 10^{2}$ & Tidak Aman \\
\hline \multirow{3}{*}{$\mathrm{A} 2$} & Piring Makan & $2 \times 10^{0}$ & $1.2 \times 10^{1}$ & $2 \times 10^{0}$ & $1.6 \times 10^{1}$ & Aman \\
\hline & Piring Saji & $1 \times 10^{0}$ & $1.8 \times 10^{1}$ & $1 \times 10^{0}$ & $2.0 \times 10^{1}$ & Aman \\
\hline & Talenan & $2.12 \times 10^{2}$ & $6.4 \times 10^{1}$ & $2 \times 10^{0}$ & $3.09 \times 10^{2}$ & Tidak Aman \\
\hline \multirow{3}{*}{ A3 } & Piring Makan & $3 \times 10^{0}$ & $7 \times 10^{0}$ & $8 \times 10^{0}$ & $1.08 \times 10^{1}$ & Aman \\
\hline & Piring Saji & $2 \times 10^{0}$ & $1.1 \times 10^{1}$ & $3.3 \times 10^{1}$ & $1.5 \times 10^{1}$ & Aman \\
\hline & Talenan & $1.06 \times 10^{2}$ & $5.3 \times 10^{1}$ & $6 \times 10^{0}$ & $1.65 \times 10^{2}$ & Tidak Aman \\
\hline
\end{tabular}

Keterangan: * Batas aman : total mikroba $=100 \mathrm{CFU} / \mathrm{cm}^{2}$ (Permenkes RI, 1989) 
nyak terdapat pada talenan yang diikuti dengan piring saji, dan piring makan. Talenan semua kantin sudah tidak aman lagi karena total hasil analisa sudah melebihi batas aman yang diijinkan. Pada talenan banyak terdapat kapang-khamir dan spora bakteri, hal ini kemungkinan karena peralatan pengolahan yang sering dipakai dan umumnya jarang dicuci.

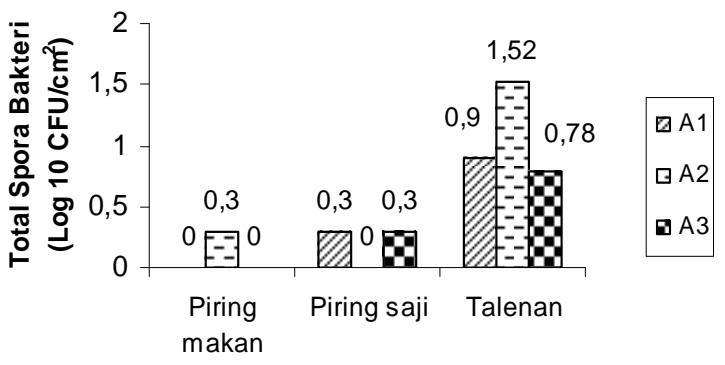

Gambar 3. Jumlah Spora Bakteri pada Peralatan di Kantin Asrama Putri TPB-IPB

Tingginya cemaran mikroba khususnya kapang-khamir pada talenan disebabkan oleh bahan pembuat talenan yang berasal dari kayu. Kayu merupakan jenis bahan yang mudah ditumbuhi oleh spora bakteri dan dapat bertindak sebagai inang untuk banyak bakteri. Sifat permukaan kayu adalah porus sehingga lebih sulit menghilangkan sisa makanan dan mikroorganisme, dan permukaan ini juga lebih lambat kering jika terkena air (Jenie, 2000).

\section{Kantin Asrama Putra TPB-IPB}

\section{Higiene tangan juru masak}

Lokasi kantin tidak berpengaruh secara nyata terhadap total mikroba, jumlah bakteri E. coli dan E. aerogenes tangan juru masak $(p>0.05)$. E. coli hanya sedikit terdapat pada tangan juru masak C1. Jumlah E. aerogenes terbanyak terdapat pada tangan juru masak C2. Staphylococcus ditemukan banyak sekali pada tangan ketiga juru masak yaitu 19-27 CFU /cawan. Lokasi kantin tidak berpengaruh terhadap jumlah Staphylococcus pada tangan juru masak.
Food handler yang terinfeksi oleh mikroorganisme patogen dapat mengkontaminasi makanan dengan memegangnya, sehingga membuka peluang timbulnya penyakit bagi yang mengkonsumsinya. Kontaminasi silang ini dapat dihindari bila food handler dilatih untuk tidak menangani makanan matang dengan tangan yang belum dibersihkan dengan baik setelah menangani makanan mentah.

Tabel 3. Jumlah Mikroba Indikator Sanitasi pada Tangan Juru Masak di Kantin Asrama Putra TPB-IPB

\begin{tabular}{|c|c|c|c|c|}
\hline \multirow[b]{2}{*}{ Kantin } & \multicolumn{4}{|c|}{ Jenis mikroba indikator sanitasi } \\
\hline & $\begin{array}{c}\text { Total } \\
\text { Mikroba }\end{array}$ & E. coli & $\begin{array}{c}\text { E. aero- } \\
\text { genes }\end{array}$ & $\begin{array}{c}\text { Staphylo- } \\
\text { coccus }\end{array}$ \\
\hline $\mathrm{C} 1$ & sedikit & sedikit & sedikit & banyak sekali \\
\hline $\mathrm{C} 2$ & banyak & $\begin{array}{l}\text { tidak } \\
\text { ada }\end{array}$ & $\begin{array}{c}\text { Agak } \\
\text { banyak }\end{array}$ & banyak sekali \\
\hline $\mathrm{C} 3$ & sedikit & $\begin{array}{l}\text { tidak } \\
\text { ada }\end{array}$ & sedikit & banyak sekali \\
\hline
\end{tabular}

Keterangan : - tidak ada (0 CFU/cawan)

- banyak (7-10 CFU/cawan)

- sedikit (1-3 CFU/cawan)

- banyak sekali (>11 CFU/cawan)

- agak banyak (4-6 CFU/cawan)

Terdapatnya bakteri pada tangan mungkin terbawa saat tangan menyentuh peralatan dapur yang kotor, makanan yang telah terkontaminasi, pakaian atau daerah tubuh lainnya. Food handler seharusnya menggunakan sanitizer saat mencuci tangan guna mengurangi mikroba. Sarung tangan plastik juga merupakan salah satu cara guna mencegah transfer bakteri patogen dari jari dan tangan ke makanan serta memberikan efek psikologi yang baik (Marriott, 1999).

\section{Sanitasi peralatan}

Kapang-khamir terbanyak pada talenan, dan tertinggi di C1, sedangkan terendah di C3 (Tabel 4 dan Gambar 4). Talenan dari semua kantin sudah tidak aman.

Tabel 4. Jumlah mikroba $\left(\mathrm{CFU} / \mathrm{cm}^{2}\right)$ berdasarkan kategori peralatan

\begin{tabular}{clccccc}
\hline \multirow{2}{*}{ Kantin } & Peralatan & $\begin{array}{c}\text { Kapang dan } \\
\text { Khamir }\end{array}$ & $\begin{array}{c}\text { Bakteri } \\
\text { Proteolitik }\end{array}$ & Spora Bakteri & Total & Kategori \\
\hline \multirow{2}{*}{ C1 } & Piring Makan & $2.0 \times 10^{2}$ & $3.6 \times 10^{1}$ & $1.8 \times 10^{1}$ & $2.5 \times 10^{2}$ & Tidak Aman \\
& Piring Saji & $7.1 \times 10^{1}$ & $5.2 \times 10^{1}$ & $1.6 \times 10^{0}$ & $1.2 \times 10^{2}$ & Tidak Aman \\
& Talenan & $2.6 \times 10^{2}$ & $9.4 \times 10^{1}$ & $4.5 \times 10^{0}$ & $3.6 \times 10^{2}$ & Tidak Aman \\
\hline \multirow{2}{*}{ C2 } & Piring Makan & $1.9 \times 10^{1}$ & $2.3 \times 10^{1}$ & $1.4 \times 10^{0}$ & $4.3 \times 10^{1}$ & Aman \\
& Piring Saji & $2.1 \times 10^{1}$ & $1.4 \times 10^{1}$ & $1.6 \times 10^{0}$ & $3.6 \times 10^{1}$ & Aman \\
& Talenan & $1.5 \times 10^{2}$ & $1.3 \times 10^{2}$ & $6.8 \times 10^{1}$ & $3.5 \times 10^{2}$ & Tidak Aman \\
\hline \multirow{2}{*}{ C3 } & Piring Makan & $2.9 \times 10^{1}$ & $1.8 \times 10^{1}$ & $1.1 \times 10^{1}$ & $5.8 \times 10^{1}$ & Aman \\
& Piring Saji & $3.8 \times 10^{1}$ & $3.4 \times 10^{1}$ & $1.8 \times 10^{0}$ & $7.4 \times 10^{1}$ & Aman \\
& Talenan & $1.3 \times 10^{2}$ & $2.5 \times 10^{1}$ & $2.6 \times 10^{0}$ & $1.6 \times 10^{2}$ & Tidak Aman \\
\hline
\end{tabular}

Keterangan : * Batas aman : total mikroba $=100 \mathrm{CFU} / \mathrm{cm}^{2}$ (Permenkes RI, 1989) 


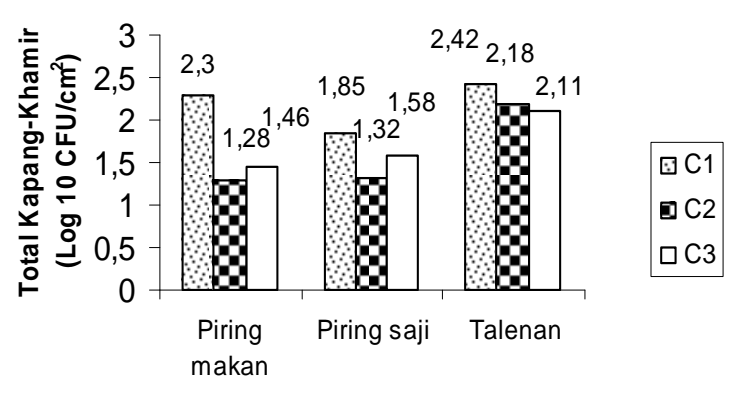

Gambar 4. Jumlah Kapang dan Khamir pada Berbagai Peralatan di Kantin Asrama Putra TPB-IPB

Lokasi kantin tidak berpengaruh nyata $(p>0,05)$ terhadap jumlah kapang dan khamir peralatan, tetapi jenis peralatan memberikan pengaruh nyata. Jumlah kapang dan khamir talenan lebih banyak secara nyata dibandingkan piring saji dan piring makan, namun tidak terdapat perbedaan nyata antara piring saji dengan piring makan.

Cemaran kapang dan khamir yang terdapat pada piring saji dan piring makan diduga berasal dari udara di sekitar lingkungan kantin ataupun penggunaan lap yang kurang bersih. Peralatan yang diletakkan begitu saja di ruang terbuka dengan posisi menengadah ke atas setelah dicuci akan menyebabkan debu maupun kotoran yang berasal dari udara dapat melekat pada alat tersebut. Lap yang digunakan untuk mengeringkan peralatan dapat bertindak sebagai sumber kontaminasi silang. Oleh karena itu, lap yang digunakan untuk mengelap peralatan harus berbeda dan dipisahkan dengan lap untuk mengelap tangan ataupun meja.

Peralatan di C1 memiliki jumlah bakteri proteolitik yang terbanyak pada piring makan dan terendah di C3 (Gambar 5). Lokasi kantin maupun jenis peralatan tidak berpengaruh nyata $(p>0.05)$ terhadap jumlah bakteri proteolitik.

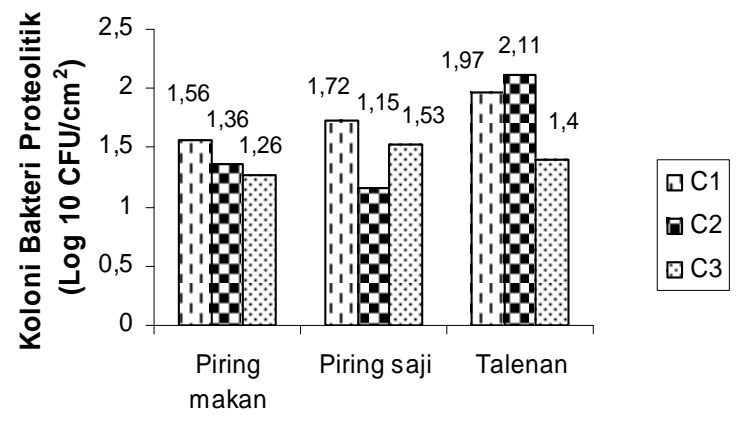

Gambar 5. Jumlah Bakteri Proteolitik pada Berbagai peralatan di Kantin Asrama Putra TPB-IPB
Bakteri proteolitik dapat memecahkan protein makanan (Fardiaz, 1992). Jumlah bakteri proteolitik pada talenan merupakan yang paling tinggi yang kemudian diikuti dengan piring saji dan piring makan. Tingginya jumlah bakteri proteolitik talenan diduga disebabkan talenan tersebut sering digunakan untuk memotong bahan makanan yang mengandung protein tinggi dan pencucian yang kurang bersih.

Jumlah spora bakteri terbanyak di C2, lalu C1 dan C3 (Gambar 6). Spora bakteri tidak ada di piring makan $\mathrm{C} 2$, namun pada talenan sangat tinggi. Lokasi kantin dan jenis peralatan tidak berpengaruh nyata terhadap spora bakteri $(p>0.05)$.

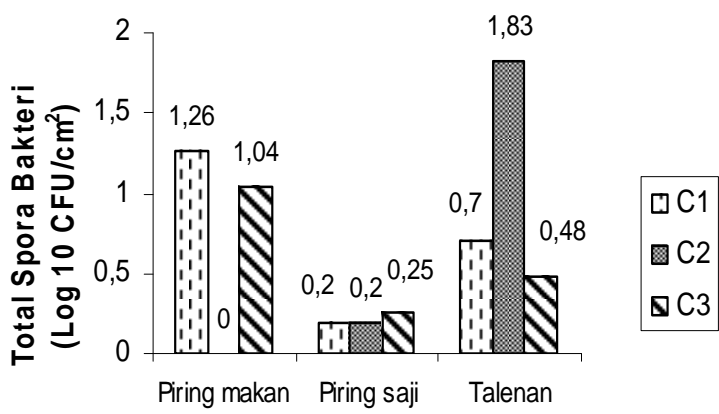

Gambar 6. Jumlah Spora Bakteri pada Berbagai Peralatan di Kantin Asrama Putra TPB-IPB

Jumlah spora bakteri pada talenan lebih tinggi daripada alat lainnya, diikuti dengan piring makan dan piring saji. Spora bakteri pada talenan dari kantin C2 15 kali lebih tinggi dibandingkan talenan dari dua kantin lainnya. Hal ini diduga disebabkan oleh kondisi talenan kantin C2 yang banyak memiliki celah (goresan) akibat bekas potongan pisau yang dapat menjadi tempat berkembangnya mikroba.

Kantin C1 tergolong tidak aman dilihat dari total mikroba yang diuji untuk semua peralatan (Tabel 4). Kantin lainnya aman untuk peralatan yang satu tetapi tidak aman untuk alat lainnya. Peralatan yang terkontaminasi mikroba akan mengkontaminasi makanan. Hal ini terbukti dari jumlah mikroba pada nasi, tongkol balado dan sop yg disajikan di kantin mengandung cukup banyak mikroba (mencapai $10^{5} \mathrm{CFU}$ ) (Damayanthi, 2004). Dalam persiapan makanan, food handler harus menggunakan peralatan dan tidak dengan tangan. Sendok atau garpu yang bersih dapat digunakan untuk mencicip makanan dan tidak menggunakannya kembali tanpa mencuci, membilas dan mensanitasikannya terlebih dahulu (Anonim, 2005) 
Pembersihan peralatan menggunakan metode yang hampir sama di semua kantin. Pembilasan menggunakan bak cuci, dan terkadang pencucian peralatan makan dan masak di cuci di tempat yang sama. Pengeringannya pun hanya dengan menaruh peralatan di rakrak penyimpanan tanpa dilap menggunakan lap yang bersih.

Menurut Anonim (2005) cara mencuci peralatan yang benar adalah pembuangan sisa makanan, melakukan pencucian awal, mencuci dengan larutan detergen dan air hangat $110^{\circ} \mathrm{F}$, membilas dengan air panas dan bersih, direndam ke dalam larurtan sanitazer selama setengah menit, dan terakhir mengeringkan peralatan dengan udara panas dan tidak mengelapnya, karena lap dapat menyebarkan bakteri.

\section{Pembahasan Umum}

Secara umum jika dilihat dari total mikroba, E. coli, E. aerogenes, dan Staphylococcus, maka tingkat sanitasi atau kebersihan tangan juru masak kantin baik pada asrama putra maupun putri masih perlu ditingkatkan. Hal ini karena tingkat sanitasi yang rendah dapat memberi dampak yang buruk terhadap kualitas mikrobiologis makanan yang dihasilkan dan akhirnya merugikan kesehatan mahasiswa yang makan di kantin.

Lokasi kantin baik di asrama putri maupun di asrama putra tidak berpengaruh terhadap Total mikroba, E. coli, dan Staphylococcus, tetapi berpengaruh terhadap E. aerogenes pada Kantin Asrama Putri. Kantin A2 menyebabkan jumlah $\mathrm{E}$. aerogenes pada tangan juru masak banyak secara nyata $(p<0.5)$ dibandingkan $\mathrm{A} 1$ dan $\mathrm{A} 3$

E. coli merupakan bakteri indikator sanitasi yang dapat digunakan sebagai petunjuk adanya pencemaran feses hewan atau manusia. Masih ditemukan E. coli di tangan juru masak kantin A3 dan $\mathrm{C} 1$ perlu mendapat perhatian yang serius karena merupakan salah satu koliform fekal yang hidup secara normal di dalam saluran pencernaan hewan dan manusia (Fardiaz, 1992).

Tabel 1 dan 3 menunjukkan Staphylococcus adalah bakteri yang paling banyak pada tangan juru masak. Baird Parker (2000) menyatakan S. aureus menyebabkan penyakit dan intoksikasi. Pencegahan keracunan makanan akibat enterotoksin adalah mencegah para food handler yang diketahui mengidap infeksi Staphylococcus untuk bekerja di ruangan pengolahan makanan dan senantiasa menjaga kebersihan dan membiasakan mencuci tangan.
Jumlah mikroba pada tangan juru masak merupakan perwujudan dari tindakan mereka terhadap sanitasi. Hasil penelitian yang dilakukan Damayanthi (2004) menunjukkan untuk kantin di Asrama Putri secara umum 58\% food handler memiliki tindakan sanitasi yang termasuk ke dalam kategori baik, sedangkan pada asrama putra $54 \%$ food handler tergolong sedang. Mereka bertindak kadang baik, kadang buruk, serta belum dapat menerapkan prinsip sanitasi dan higiene dengan benar.

Kuswanti (2002) melaporkan bahwa di kantin Sapta Darma Fakultas Teknologi Pertanian, semua tangan food handler $(100 \%)$ ternyata mengandung Staphylococcus dan bakteri koliform. Hal ini menunjukkan bahwa penerapan higiene perorangan food handler makanan belum dilaksanakan dengan baik dan benar. Salah satu cara yang efektif untuk mengurangi Staphylococci pada tangan food handler adalah dengan pencucian menggunakan sabun antiseptik. Penggunaan larutan iodium $0.4 \%$ dan Dettol $4 \%$ dapat mengurangi total mikroba, Staphylococci dan bakteri koliform pada tangan. Untuk menghindari terjadinya kontaminasi silang Staphylococcus dari bahan mentah ke matang, maka penanganan bahan pangan khususnya pada tahap persiapan harus diperhatikan.

Berdasarkan jumlah kapang-khamir, bakteri proteolitik, dan spora bakteri, maka beberapa peralatan termasuk dalam kategori tidak aman (Tabel 2 dan 4). Peralatan dari C1 relatif tidak aman karena jumlah mikroba semua peralatan $>100 \mathrm{CFU} / \mathrm{cm}^{2}$. Jumlah kapangkhamir, bakteri proteolitik maupun spora bakteri pada peralatan tidak dipengaruhi oleh lokasi kantin. Jumlah kapang dan khamir peralatan di Kantin Asrama Putri relatif lebih sedikit dibandingkan di Kantin Asrama Putra.

\section{KESIMPULAN}

Food handler baik pada kantin asrama putri mau pun putra masih perlu ditingkatkan kesadarannya untuk menerapkan prinsip sanitasi dan higiene dengan baik dan benar. Hal ini dikarenakan mikroba indikator sanitasi masih terdapat pada tangan semua food handler. Pencucian tangan dengan air saja masih kurang sehingga perlu dibiasakan menggunakan sabun.

Mikroba indikator sanitasi pada tangan juru masak di Kantin Asrama Putra dan Putri TPB-IPB ditemui dengan kategori tidak ada hingga kategori banyak sekali (> $11 \mathrm{CFU}$ ). Jumlah total mikroba, E. coli, E. aerogenes dan 
Staphylococcus tidak dipengaruhi oleh lokasi kantin juru masak tersebut bekerja, kecuali E. aerogenes pada Kantin Asrama Putri.

Kantin A2 dan C2 mengandung banyak total mikroba, bahkan A1 banyak sekali, sedangkan lainnya hanya sedikit. Tangan juru masak kantin $\mathrm{C} 1$ dan $\mathrm{A} 3$ belum terbebas dari bakteri E. coli, sedangkan tangan juru masak kedua kantin lainnya sudah terbebas dari bakteri E. coli. Kantin A2 secara nyata banyak mengandung $E$. aerogenes. Staphylococcus merupakan mikroba indikator pada tangan juru masak yang ditemui merata banyak sekali pada semua kantin. Staphylococcus merupakan bakteri terbanyak di antara jenis bakteri lainnya. Staphylococcus tangan juru masak Asrama Putri berkisar 44 -57 CFU/cawan, sedangkan di Asrama Putra 19-27 CFU/cawan.

Tidak ada dari semua peralatan pengolahan dan penyajian di semua kantin yang jumlah kandungan mikrobanya benar-benar aman, pada C1 semua peralatan tidak aman secara mikrobiologis. Perlu dilakukan penyuluhan mengenai teknik pencucian, pengeringan dan penyimpanan peralatan pengolahan dan makan serta penyediaan fasilitas sanitasi yang lebih baik.

Dari semua jenis peralatan, semua talenan di semua kantin tidak aman secara mikrobiologis sehingga memberikan risiko ketidak amanan yang paling besar. Jumlah mikroba tertinggi terdapat pada talenan dengan mikroba jenis kapang-khamir sebesar $212 \mathrm{CFU} / \mathrm{cm}^{2}$ di Kantin Asrama Putri dan sebesar 260 CFU/ $\mathrm{cm}^{2}$ di Kantin Asrama Putra. Jumlah mikroba terendah terdapat pada piring makan kantin A1 pada kapang khamir yaitu sebesar 0 CFU/ $\mathrm{cm}^{2}$.

\section{DAFTAR PUSTAKA}

Anonim. 2003. Bacteria and Foodborne Illness. http://www.digestive.niddk. nih.gov.

2005. Foodborne Pathogenic Microorganisms and Natural Toxins Handbook. http://www.usfda.com/ Staphilococcus. html

2005. Manual Pemberantasan Penyakit Menular. http://www. ppmplp. depkes.go.id.

2005. Food Handler's Manual. http: //www.comultnomah. ur.us.
Badan POM RI. 2005. Direktorat Surveilan dan Penyuluhan Keamanan Pangan. Jejaring Promosi Keamanan Pangan dan Keamanan Pangan Jajanan Anak Sekolah. Disampaikan pada Lokakarya Jejaring Promosi Keamanan Pangan Jajanan Anak Sekolah, Jakarta, 12 Mei 2005.

Baird-Parker TC. 2000. Staphylococcus aureus. Dalam Lund BM, Baird-Parker TC, \& Gould GW (Eds.), The Microbiological Safety and Quality of Food (hlm. 13191321). Aspen Publishers, Maryland.

Damayanthi E, 2004. Studi Keamanan Mikrobiologis pada Kantin Asrama Putra dan Putri, Tingkat Persiapan Bersama - Institut pertanian Bogor. Laporan akhir Hibah Penelitian. Proyek Due-Like T.A. 2004.

Fardiaz S. 1992. Petunjuk Praktikum Mikrobiologi Pengolahan Pangan. Direktorat Jenderal Pusat Antar Universitas. IPB, Bogor.

Jenie BSL. 1999. Sanitasi dan Higiene pada Pengolahan Pangan. Makalah Disajikan dalam Pelatihan Mutu dan Keamanan Pangan bagi Staf Pengajar, Bogor, 2-14 Agustus.

2000. Sanitasi dan Higiene Pada Pengolahan Pangan. Diktat yang tidak dipublikasikan, Pusat Studi Pangan dan Gizi, IPB, Bogor.

\& Fardiaz S. 1989. Petunjuk Laboratorium Uji Sanitasi dalam Industri $\mathrm{Pa}$ ngan. Pusat Antar Universitas (PAU) Pangan dan Gizi, Institut Pertanian Bogor.

Kuswanti Y. 2002. Studi Kondisi Sanitasi Kantin Fateta-IPB. Skripsi Sarjana. Jurusan Teknologi Pangan dan Gizi, Fakultas Teknologi Pertanian, Institut Pertanian Bogor.

Marriott NG. 1999. Principles of Food Sanitation. Fourth ed. An Aspen publ., Inc. Maryland.

Peraturan Menteri Kesehatan RI No. 304/ MENKES/PER/IV/1989 tentang Persyaratan Kesehatan Rumah Makan dan Restoran dan Petunjuk Pelaksanaannya. Departemen Kesehatan RI, Jakarta. 